\title{
O Sanitarismo brasileiro dos anos 30: a aventura dos relatos dos seus agentes de campo
}

CUNHA, N eivaVieira.

Viagem, experiência ememória: narrativasdeprofissionaisda SaúdePública dosanos 30.

Bauru, SP: Edusc, 2005 (C oleção Ciências Sociais). 330p.

\section{Vanessa Maia Rangel I}

Doutoranda no Instituto de Medicina Social da UERJ, área de Política, Planejamento e Ações em Saúde; bolsista do CNPq. Endereço eletrônico: tufaha@terra.com.br.

O livro de $\mathrm{N}$ eiva V ieira da C unha me veio às mãos a partir de um contato pela internet com a própria autora. Embora não a conheça pessoalmente, o contato foi estabelecido por interesses em comum pertinentes à área da Saúde Pública.

Trabalho premiado no C oncurso ED U SC-AN PO CS em 2004, representa, a meu ver, uma poética obra que narra a aventura do Sanitarismo brasileiro nos anos 30, a partir dos relatos de entrevistas com profissionais relativamente anônimos, se comparadosa Pasteur ou a $\mathrm{O}$ swaldo $\mathrm{C}$ ruz, mas que, da perspectiva da autora, ajudaram a construir o campo da Saúde Pública brasileira na sua dimensão simbólica, através das lembranças dos velhos tempos de campanha, das longas viagens a trabalho edas experiências do campo. D esta maneira, a autora elabora uma etnografia retrospectiva onde as campanhas, as viagens e a experiência do campo são, portanto, as categorias nativas capturadasnos discursos dos seus entrevistados, especialmentenosminuciosos e pictóricos relatos do D r. C elso Arcoverde, informanteprivilegiado epara quem vai uma homenagem especial no livro.

A importância dessa obra parece estar tanto no seu aspecto político quanto antropológico. Primeiro, pela possi bilidadequetem de mostrar uma preocupação do Estado brasileiro da época, cerca dos anos 20 e 30, com o "Brasil D oente": aspecto que passa a ser denunciado a partir de uma mudança de pensamento na área da saúde, originada na Revolução Pasteuriana. E segundo, pela rica análise da construção das identidades sociais dos agentes sanitários que se revela a partir dos caminhos percorridos por esta escolha profissional. 
O capítulo 1, "O Campo da Saúde Pública no Brasil", é um capítulo histórico que descreve alguns aspectos da Reforma Sanitária dos anos 20, o modelo do Sanitarismo brasileiro e a criação dos M inistérios da Educação e Saúde. D estaca a importância da febre amarela, varíola e a peste como representantes das doenças infecciosas que foram combatidas pelos porta-vozes da Revolução Pasteuriana brasileira na época: 0 swal do C ruz, Carlos C hagas, Arthur N eiva e Belisário Pena.

Segue o segundo capítulo, mais metodológico, no qual a autora utiliza a escolha pela Saúde Pública como dispositivo para deflagrar determinadas recordações que fizeram a construção, em conjunto com os agentes do campo da Saúde Pública, de um projeto emissão eque, a partir deum referencial quase ingênuo decuriosidade, renúncia e despojamento, passa a almejar a carreira de um serviço público com prestígio e reconhecimento social.

As viagens de inspeção einvestigação são descritas no capítulo três, val orizando a possibilidade de esses profissionais conhecerem, através delas, a realidade de todo 0 país e aprimorar os conhecimentos em matéria de Saúde Pública. Estas viagens são percebidas pela autora como eventos necessários para a construção das experiênciase identidades no campo do Sanitarismo da época, implicando uma disposição franca para a aventura deviver o extraordinário, conotação semelhanteà viagem etnográfica.

Ainda dentro de uma perspectiva de desbravamento do interior do Brasil, o capítulo sobre o campo e seus procedimentos discute as viagens de investigação como oportunidades de troca entre os saberes científico epopular, enfatizando, no entanto, o caráter de ordem e de pureza que o saber científico dos sanitaristas proclamava levar para as populações mais distantes dos centros urbanos. A autora enfatiza a vertente simbólica dos procedimentos empregados pelos sanitaristas como pertencentes a um sistema total de apreensão do mundo, uma cosmologia que seria transmitida e disseminada pelos jovens sanitaristas.

Concluindo, o livro de $\mathrm{N}$ eiva V ieira da C unha destaca o Sanitarismo brasileiro dos anos 30 como uma política de instituição de uma nova visão no mundo da saúde, que, a partir da Revolução Pasteuriana, introduz a simbologia da impureza através da categoria da doença/patogenia. Esta visão étransmitida pelas campanhas sanitárias, que representam, num sentido de crise, um risco pelo enfrentamento da contaminação, ao mesmo tempo em que são a oportunidade de cientifização do meio ambiente e dos corpos daquel es que porventura fossem afetados. 